\title{
The Effect of Academic Supervision and School Culture on the Completeness of Learning Administration for Senior High School Teachers
}

\author{
Rustini $^{1 *}$, Happy Fitria ${ }^{2}$, Yenny Puspita ${ }^{2}$
}

\author{
${ }^{I}$ SMA Negeri 1 Buay Sandang Aji \\ ${ }^{2}$ Universitas PGRI Palembang \\ *Corresponding author. Email: rustinialhadi@gmail.com
}

\begin{abstract}
This research aims to determine the effect of the principal's academic supervision and school culture on the completeness of the administration of learning for the State Senior High schools in OKU Selatan. This research used quantitative correlational methods. The research population was 21 the State Senior High schools in OKU Selatan. Sampling was based on representative and proportional school accreditation rankings as many as 160 teachers from 5 State Senior High schools in OKU Selatan. Data collection techniques used in this research were questionnaires and documentation. The results of the study stated that as much as $34.5 \%$ of the principal's academic supervision had an effect on the completeness of teacher learning administration and as much as $33.2 \%$ of the school culture had an effect on the completeness of the teacher's learning administration as well as the academic supervision of the principal and school culture had an effect on the completeness of the administration of learning for teachers of the State Senior High School in the OKU Selatan together amounted to $35.8 \%$.
\end{abstract}

Keywords: Academic Supervision, School Culture, Completeness of Learning Administration.

\section{INTRODUCTION}

One of the efforts made to improve human resources is through education, namely by improving the learning process in schools. Education is one indicator of a country's progress. The existence of the principal in an educational institution is one of the keys and is required to be able to condition the professional work climate. The success of a school in improving the quality of education in schools cannot be separated from the leadership of a school principal. Teachers also have a very important role in improving the quality of human resources [1]. Therefore, to become a professional staff, efforts are needed to improve the quality of teacher teaching, because improving the quality of education depends on many things, especially the quality of teachers.

The success of students in the learning process is strongly influenced by how the teacher teaches, the teacher not only functions to transfer knowledge but also has the duty to provide skills and change the attitudes and behavior of students. This is in accordance with Law Number 14 of 2005 concerning Teachers and Lecturers which states that a teacher is a professional educator with the main task of educating, teaching, guiding, directing, training, assessing, and evaluating students on the path of formal education, basic education., and secondary education [2].

Many factors affect the quality of an education, such as the principal's leadership style, principal managerial, teacher quality, students, facilities and infrastructure, work culture, learning administration, curriculum and so on [3]. School leadership is an activity to direct, influence and control all the potential of the school which is carried out by the principal in a systematic and programmed manner in order to achieve organizational goals.

The principal in the school environment is the person who is responsible for the realization of all activities in the best possible coordination. The principal must have the ability to lead the school as a whole. In the regulation of the Minister of National Education Number 20 of 2003, it explains that the competence of the principal includes: 1) personality competence; 2) managerial competence; 3) Entrepreneurial competence; 4) supervisory competence; 5) social competence. UU RI (2003)

From the regulation of the Minister of National Education Number 13 of 2007 above, states that principals must have supervisory competencies in order to provide assistance or guidance to teachers they lead 
in order to improve teacher professionalism in teaching. In addition to functioning as managerial supervisors, the principal is also an academic supervisor. As an academic supervisor, the principal has an obligation to help teachers become professionals so that teachers can improve the quality of the learning process. With the assistance of supervision from the principal, it is hoped that the results of the implementation of the learning process in schools will be better and of quality so that the goals of education will be achieved.

According to [4], in his research, he states that in addition to school academic supervision as a supervisor to improve the learning process, it is also influenced by many other factors such as school culture, leadership, job satisfaction, school environment, school organizational climate as well as other factors.

In addition to the role of school principal academic supervision and the role of teachers in improving the quality of education [5], there are other things that must be considered, namely school culture because with the school culture, we will be able to find out how the description of teaching and learning activities is especially related to the teacher as the tip of the arrow in the world of education. School culture is an element in improving the quality and achievement of education.

School culture is an organizational culture in the context of schooling, the quality of life of an ordinary school can be seen in the form of how school principals, teachers and other education personnel work, learn and relate to one another, as has become a school tradition. School culture improves school performance and builds school quality.

According to the results of research by [6] which states that, the better academic supervision, the better the teaching quality of teachers, and school culture is a condition that can be used to motivate work and improve teacher performance, especially in carrying out the learning process. From this research it can be stated that with good quality of supervision and school culture, it has a high effect on the effectiveness of learning. In line with research conducted by [7] which states that teachers who supervise are more motivated in teaching, especially supported by a good school culture, so teacher job satisfaction will also increase.

Academic supervision and school culture in addition to influencing the effectiveness of learning also affects the quality of teacher teaching, teacher achievement, teacher teaching performance and teacher competence in preparing learning administration. As stated in the results of research by [2] in his research on the application of academic supervision, to improve teacher competence in compiling administration of assessments at the Salatiga Laboratory Elementary School, states that with good academic supervision it can improve the ability of teachers in the administration of learning assessment amounted to $26.2 \%$. This research is also supported by the results of research by [8], that the competence of teachers in compiling learning administration has an important role in realizing effective work performance and organization. And according to the opinion of [9], that the administration sector supports the teaching and learning process in the context of implementing education, it is impossible for the implementation of education to be carried out if there is no good learning administration support as well.

The teacher's ability to carry out learning administration greatly affects the creation of an effective learning process. Therefore, teachers as the spearhead in the educational process who are directly involved with the teaching and learning process [10] [11]. The teaching and learning process will go well with what is expected in accordance with the goals of education.

Learning administration includes an annual program, semester program, syllabus, lesson plan (RPP), assessment and remedial which is a concept or design of a teacher in transferring knowledge to students systematically [12], without a plan and standards in teaching, the teaching material given to students will not be conveyed systematically. Therefore, a teacher must be able to carry out learning administration well.

The teacher must be aware of the importance of learning administration because if the teacher is able to carry out the administration of learning properly [13], an effective learning process will be created. This is of course influenced by several factors which consist of several components, including the leadership of the principal in carrying out his main duties and also a supportive school culture. This is in line with the results of research conducted by [14] which states that there is a significant influence between the supervision of the principal and school culture on the administration of teacher learning in the Elementary School, Belitang Madang Raya District, East OKU Regency. In this study, it is explained that if the principal's academic supervision is carried out with careful preparation and regular frequency, and is carried out jointly and supported by the development of a conducive school culture, it will support the expected learning method, namely better education quality.

From the results of the above research, the implementation of an effective educational interaction process, especially in an effort to increase teacher awareness of the importance of completeness of learning administration in the teaching and learning process, is supported by a good school culture and the function of academic supervision of principals which is well implemented as well. The teacher's awareness of the importance of completeness of learning administration cannot be separated from the teacher's commitment. In accordance with the results of research conducted by [15], namely the formation of school culture and always carrying out academic supervision influencing teachers to become increasingly committed to the school where they work.

From the results of initial observations by researchers at Senior High Schools in South OKU 
Regency on August 3 to 15, 2020, researchers obtained information that the observed high schools had adequate facilities. In addition, from observations and interviews / initial discussions of researchers, researchers found that the implementation of supervision was limited to a formality and had not been carried out regularly, and the follow-up and reflection of supervision activities had not been carried out properly, some teachers had not been optimal in carrying out their profession as teachers, especially in implementing teaching and learning processes such as, have not developed curriculum and syllabus due to lack of understanding, incomplete planning of learning and some have not even made learning tools because of busy reasons or unable to use IT.

Another problem is that the teacher has not been optimal in carrying out the learning process by means of monotonous teaching without following the design of the learning process that has been made. Sometimes when being supervised, they only prepare the learning tools to be used, and in practice there are those who follow the lesson plans that are made but seem stiff and some are not suitable, but when after being supervised some teachers will return to teaching their original habits, it seems that the supervision activities have no impact nothing because of the lack of follow-up results of supervision by the principal. The availability of learning administration documents is not complete for all teachers, especially lesson plan documents.

From the conditions found by the researchers above, in addition to the supervision of the principal and the completeness of teacher learning administration, an indicator is that the school is still unable to build a conducive school culture, including developing a school culture that can build teacher discipline, teacher achievement spirit, and teacher performance. especially in the completeness of learning administration.

From some of the conditions that have been described above, the researcher will conduct research that aims to obtain information data about "The Effect of Principal Academic Supervision and School Culture on the Completeness of Educational Administration for Public High School Teachers in South OKU Regency".

\section{METHODS}

This research uses correlational quantitative research, where all stages of the research are numbers and data to determine the relationship between two variables [16].

The variables in quantitative research here consist of: academic supervision of the principal $\left(\mathrm{X}_{1}\right)$ on the completeness of teacher learning administration (Y), School Culture $\left(\mathrm{X}_{2}\right)$ on the implementation of teacher learning administration (Y), and academic supervision of the principal $\left(\mathrm{X}_{1}\right)$ and School culture $\left(\mathrm{X}_{2}\right)$ on the completeness of teacher learning administration $(\mathrm{Y})$. To test the hypothesis that has been formulated, all data obtained will be processed and processed by quantitative analysis.

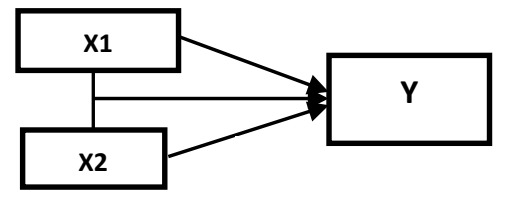

Figure 1. Research Variables

Information:

$\mathrm{X}_{1}=$ Principal Academic Supervision

$\mathrm{X}_{2}=$ School Culture

$\mathrm{Y}=$ Completeness of the teaching administration of Teachers

$$
\begin{aligned}
& \mathrm{H}_{1}=\text { Effect } \mathrm{X}_{1} \text { on } \mathrm{Y} \\
& \mathrm{H}_{2}=\text { Effect } \mathrm{X}_{2} \text { on } \mathrm{Y} \\
& \mathrm{H}_{3}=\text { Effect } \mathrm{X}_{1} \mathrm{X}_{2} \text { on } \mathrm{Y}
\end{aligned}
$$

The population in this study were all State Senior High Schools (SMA) in South Oku Regency which consisted of 21 Public Senior High Schools with a total of 703 teachers. people, while the research sample consisted of 160 teachers from 5 public high schools, namely SMAN 1 Buay Sandang Aji, SMAN 1 Muaradua, SMAN 1 Buay Rawan, SMAN 1 Tiga Dihaji and SMAN 2 Muaradua. The sampling technique in this study was using random sampling technique based on the level of accreditation that is representative and proportional.

Data collection techniques in this study used questionnaires and documentation. The trial of this instrument was tested on teachers who were not included in the sample, namely as many as 40 teachers who were taken from the population carried out at SMA Negeri 1 Buay Pemaca, then tested the validity and reliability using SPSS version 22. The results of the questionnaire that were filled in by The sample were tested for analysis prerequisite, namely; 1) Normality Test, 2) Linearity Test, and 3) Multicollinearity Test.

The research data were tested through several stages such as Multiple Regression Test, T Test, F Test (simultaneous),

and the Coefficient of Determination. Testing each data analysis using the help of the SPSS version 22.0 application. The explanation for each data analysis is as follows.

\section{a. Multiple Linear Regression}

The amount of influence between variables can be seen through the value $R$ square of the analysis results. The existing $R$ square value shows the magnitude (\%) of the effect of variable $\mathrm{X}$ on variable $\mathrm{Y}$, namely the effect of academic supervision and school culture on the completeness of teaching administration for teachers of SMA Negeri 1 South OKU Regency. Multiple linear regression equation, namely:

$$
\mathrm{Y}=\mathrm{a}+\mathrm{b} 1 \mathrm{X} 1+\mathrm{b} 2 \mathrm{X} 2+\mathrm{bn} \mathrm{Xn}
$$




\section{Description:}

Y. $=$ Subject dependent variable

$\mathrm{X} .=$ Independent variable

$\mathrm{a}=$ constant value

$\mathrm{b}=$ direction value as a determinant of the prediction shows the value of the increase $(+)$ or decrease in the value (-) of the variable $\mathrm{Y}$

b. T test (partial).

The decision making or the conclusion of the $t$ test using SPSS is based on the probability (significance) results obtained. The probability criteria for drawing conclusions are as follows.

1) The effect of academic supervision on the completeness of teacher learning administration.

If the significance $\alpha>0.05$ or $t$ count $<\mathrm{t}$ table, then Ho is accepted. That is, there is no effect of academic supervision on the completeness of teacher learning administration.

If the probability $\alpha<0.05$ or $t$ count $>\mathrm{t}$ table, then $\mathrm{Ha}$ is accepted. That is, there is an effect of academic supervision on the completeness of teacher learning administration.

2) The influence of school culture on the completeness of teacher learning administration

If the significance is $\alpha>0.05$ or $t$ count $<\mathrm{t}$ table, then Ho is accepted. That is, there is no influence of school culture on the completeness of teacher learning administration.

If the probability $\alpha<0.05$ or $t$ count $>t$ table, then Ha is accepted. That is, there is an influence of school culture on the completeness of teacher learning administration.

c. F test (Simultaneous)

This test is carried out simultaneously with multiple regression testing using the help of the SPSS version 22.0 program. Decision making is based on the probability values obtained, which are as follows.

1) If the probability (significant) $>0.05(\alpha)$ or $F$ count $<F$ table, it means that the hypothesis is not proven, then $\mathrm{HO}$ is accepted. Ha is rejected if it is done simultaneously. This means that there is no relationship between the influence of academic supervision and school culture on the completeness of learning administration in SMA Negeri OKU Selatan Regency.

2) If the probability (significant) $<0.05(\alpha)$ or F count $>$ $\mathrm{F}$ table means that the hypothesis is proven, then $\mathrm{HO}$ is rejected and $\mathrm{Ha}$ is accepted if it is done simultaneously. This means that there is a relationship between the influence of academic supervision and school culture on the completeness of learning administration in SMA Negeri OKU Selatan Regency.

\section{RESULTS AND DISCUSSION}

\section{Research Results}

This study was conducted from August 2020 to December 2020. The data analysis process in this study used the SPSS version 22.0 program. The data that has been obtained from the distribution of questionnaires outside the sample of 40 respondents were tested for validity and reliability with the results, for the academic supervision variable $\left(\mathrm{X}_{1}\right)$ of 28 valid statements of 25 statements, the school culture variable $\left(\mathrm{X}_{2}\right)$ of 26 statements of 24 valid statements and for the learning administration completeness variable $(\mathrm{Y})$ there were 26 valid statements from the 30 statements tested. Whereas in the reliability test, the Cronbach's Alpha value $\left(\mathrm{r}_{\text {count }}\right)$ is greater than the $r$ table, which states that the data obtained is declared reliable.

After the questionnaire was declared valid and reliable, the questionnaire was distributed to 160 sample teachers, and after the data was obtained several tests were carried out including:

\section{A. Data Analysis Requirements}

\section{Normality Testing}

Normality test aims to test whether in the regression model, the dependent variable and the independent variable both have normal distribution or not. In this study, the normality test used the Kolmogorov-Smirnov test using SPSS version 22.0. The results of the Kolmogorof-Smirnov normality test obtained the following data.

Table 1

Normality Test of Academic Supervision Variables and School Culture on Completeness of Teacher Learning Administration (Variable $\mathrm{X}_{1}, \mathrm{X}_{2}-\mathrm{Y}$ ) One-Sample Kolmogorov-Smirnov Test

\begin{tabular}{|ll|r|}
\hline & & \multicolumn{2}{|c|}{$\begin{array}{c}\text { Unstandardized } \\
\text { Residual }\end{array}$} \\
\hline $\mathrm{N}$ & Mean & 160 \\
Normal Parameters' ${ }^{\mathrm{b}}$ & Std. Deviation & .0000000 \\
& Absolute & .84885742 \\
Most Extreme Differences & .037 \\
& Positive & .037 \\
& Negative & -.030 \\
Test Statistic & & .037 \\
Asymp. Sig. (2-tailed) & & $.200^{\mathrm{c}, \mathrm{d}}$ \\
\hline
\end{tabular}

Source: Data processing using SPSS version 22

Based on the table above, it is known that the significance value of the variable $\mathrm{X}_{2}$ to $\mathrm{Y}$ is 0.200 greater than 0.05 , so the data for variables $X_{1}, X_{2}-Y$ are normally distributed. 
Normal P-P Plot of Regression Standardized Residual

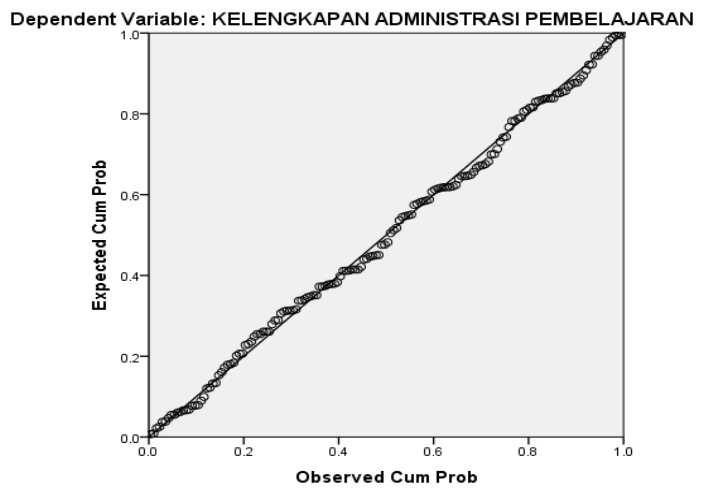

Figure 2. Normal PP Plot of variables $X_{1}, X_{2}-Y$ (Source: Data processing using SPSS version 22.0)

Based on the picture above, it can be seen that the data spreads around the diagonal line and follows the direction of the diagonal line showing that the data has a normal pattern, so the dependent variable $\mathrm{Y}$ meets the normality assumption.

\section{Linearity Test}

Linearity test aims to determine whether two variables have a significant relationship or not. A good correlation should have a linear relationship between the independent variable (X) and the dependent variable (Y). In this study, the linearity test used SPSS pesi 22.0.

Table 2

Linearity test of variable $\mathrm{X}_{1}$ with variable $\mathrm{Y}$ ANOVA Table

\begin{tabular}{|c|c|c|c|c|c|c|c|}
\hline & & & $\begin{array}{c}\text { Sum of } \\
\text { Squares }\end{array}$ & df & $\begin{array}{l}\text { Mean } \\
\text { Square }\end{array}$ & $\mathbf{F}$ & Sig. \\
\hline \multirow{5}{*}{$\begin{array}{l}\text { Supervisio } \\
\text { n Of } \\
\text { Academic } \\
\text { Administra } \\
\text { tion Of } \\
\text { Learning * }\end{array}$} & $\begin{array}{l}\text { Betweer } \\
\text { Groups }\end{array}$ & $\begin{array}{l}1528,38666,4 \\
52\end{array}$ & & & & & \\
\hline & & Linearity & 1070.925 & 1 & 1070.925 & 67993 & .000 \\
\hline & & $\begin{array}{l}\text { Deviation } \\
\text { from } \\
\text { Linearity }\end{array}$ & 457460 & 22 & 20794 & 1.320 & .169 \\
\hline & \multicolumn{2}{|c|}{ Within Groups } & 2142.058 & 136 & 15,750 & & \\
\hline & \multicolumn{2}{|l|}{ Total } & 3670.444 & 159 & & & \\
\hline
\end{tabular}

Source: Processing of data using SPSS version 22

Based on the table above, it is obtained a significance value of 0.169 which is greater than 0.05 , which means that there is a significant linear relationship between the $\mathrm{X} 1$ variable (academic supervision) and the $\mathrm{Y}$ variable (learning administration completeness). Then obtained F-count $=1.30$, while $\mathrm{F}$ table in the distribution table the value of F 0.05 with the number df 22 Ftable $=1.60$. Because Fcount is smaller than Ftable, it can be concluded that there is a significant linear relationship between the $\mathrm{X} 1$ variable (academic supervision) and the $\mathrm{Y}$ variable (learning administration completeness).
Table 3

Linearity test for variable $\mathrm{X}_{2}$ with variable $\mathrm{Y}$

ANOVA Table

\begin{tabular}{|c|c|c|c|c|c|c|c|}
\hline & & & $\begin{array}{l}\text { Sum of } \\
\text { Squares }\end{array}$ & df & $\begin{array}{l}\text { Mean } \\
\text { Square }\end{array}$ & $\mathrm{F}$ & Sig. \\
\hline \multirow{5}{*}{$\begin{array}{l}\text { Administ } \\
\text { ration of } \\
\text { culture } \\
\text { school } \\
\text { learning } \\
*\end{array}$} & $\begin{array}{l}\text { Between } \\
\text { Groups }\end{array}$ & $1306,82559,401$ & & 22 & $\begin{array}{l}\text { (Combin } \\
\text { ed) }\end{array}$ & & .000 \\
\hline & & Linearity & 915258 & 1 & 915258 & 53050 & .000 \\
\hline & & $\begin{array}{l}\text { Deviation from } \\
\text { Linearity }\end{array}$ & 391567 & 21 & 18646 & 1,081 & .376 \\
\hline & \multicolumn{2}{|c|}{ Within Groups } & 2363.618 & 137 & 17253 & & \\
\hline & \multicolumn{2}{|l|}{ Total } & 3670.444 & 159 & & & \\
\hline
\end{tabular}

Source: Processing of data using SPSS version 22

Based on the table above, the significance value of 0.376 is greater than 0.05 , which means that there is a significant linear relationship between the $\mathrm{X}$ variable $_{2}$ (School Culture) and the $\mathrm{Y}$ variable (learning administration completeness). Then obtained $\mathrm{F}_{\text {count }}=$ 1.081 , while the $\mathrm{F}_{\text {table }}$ in the distribution table $\mathrm{F}$ value of 0.05 with the number df $21 \mathrm{~F}_{\text {table }}=1.62$. Because $F_{\text {count }}$ is smaller than $F_{\text {table, }}$ it can be concluded that there is a significant linear relationship between variable $\mathrm{X}_{2}$ (School Culture) and variable $\mathrm{Y}$ (completeness of learning administration).

\section{Multicollinearity Test}

Multicollinearity test aims to prove whether the regression model found a correlation between the independent variables [17]. A good regression model should not find a correlation between the independent variables, if there is a relationship between the independent variables, a symptom called the multicollinearity problem will arise.

Table 4

Test of Multicollinearity

\begin{tabular}{|c|c|c|c|c|c|c|c|}
\hline \multicolumn{8}{|c|}{ Coefficients } \\
\hline \multirow{2}{*}{ Model } & \multicolumn{2}{|c|}{$\begin{array}{l}\text { Unstandardized } \\
\text { Coefficients }\end{array}$} & \multirow{2}{*}{\begin{tabular}{|c|}
$\begin{array}{c}\text { Standardize } \\
\text { d } \\
\text { Coefficients }\end{array}$ \\
Beta \\
\end{tabular}} & \multirow{2}{*}{$\mathbf{T}$} & \multirow{2}{*}{ Sig. } & \multicolumn{2}{|c|}{$\begin{array}{c}\text { Collinearity } \\
\text { Statistics }\end{array}$} \\
\hline & B & \begin{tabular}{|c|} 
Std. \\
Error
\end{tabular} & & & & $\begin{array}{c}\text { Tolera } \\
\text { nce }\end{array}$ & VIF \\
\hline (Constant) & 37526 & 7805 & & 4808 & .000 & & \\
\hline $\begin{array}{l}\text { Academic } \\
\text { supervision }\end{array}$ & $\begin{array}{l}.067 \\
.385 .734\end{array}$ & & & 5,162 & .000 & .345 & 1,361 \\
\hline Culture school & $\begin{array}{l}.082 \\
.301 .734\end{array}$ & & & 4,034 & .000 & .332 & 1,361 \\
\hline
\end{tabular}

Of Resources Treatment Data using SPSS version 22

From the table above, it can be seen that the tolerance value for $\mathrm{X}_{1}$ (academic supervision) and $\mathrm{X}_{2}$ ( school culture $)=0.734$ is greater than 0.1 which states that multicollinearity does not occur. Whereas seen from the VIF value for $\mathrm{X}_{1}$ (academic supervision) and $\mathrm{X}_{2}($ school culture $)=1.361$ which is smaller than 10 , this also states that there is no multicollinearity. 


\section{B. Hypothesis Testing}

\section{Multiple Linear Regression}

According to [18] multiple linear regression is an analysis tool for forecasting the value of the effect of the independent variable or the dependent variable to prove whether or not there is a functional relationship or a causal relationship between two independent variables. This multiple linear test using SPSS version 22.0. Table 5 Multiple Linear Regression Test

\begin{tabular}{|c|c|c|c|c|c|}
\hline \multicolumn{6}{|c|}{ Coefficients } \\
\hline \multirow{2}{*}{ Model } & \multicolumn{2}{|c|}{$\begin{array}{l}\text { Unstandardized } \\
\text { Coefficients }\end{array}$} & $\begin{array}{c}\text { Standar } \\
\text { dized } \\
\text { Coeffic }\end{array}$ & \multirow{2}{*}{$\mathrm{t}$} & \multirow{2}{*}{ Sig. } \\
\hline & B & $\begin{array}{l}\text { Std. } \\
\text { Error }\end{array}$ & Beta & & \\
\hline $\begin{array}{l}37,526 \\
7,805.000\end{array}$ & & & & 4,808 & (Constant) \\
\hline $\begin{array}{l}\text { Academic } \\
\text { supervision }\end{array}$ & $\begin{array}{c}.067 \\
.385 .000\end{array}$ & & & 5,162 & .345 \\
\hline Culture school & $\begin{array}{c}.082 \\
.301 .000\end{array}$ & & & 4,034 & .332 \\
\hline
\end{tabular}

a. Dependent Variable: Completeness Of Learning Administration Source: Data processing using SPSS version 22

Based on the table above, it is found that the constant value of the regression equation a is 37.526 and the coefficient value of the independent variable b1 is 0.345 and $b 2$ is 0.332 , the following regression equation is obtained.

$\mathrm{Y}=\mathrm{a}+\mathrm{b} 1 \mathrm{X} 1+\mathrm{b} 2 \mathrm{X} 2$

$\mathrm{Y}=37.526+0.345 \mathrm{X} 1+0.332 \mathrm{X} 2$

This means that the completeness of teacher learning administration has increased positively with academic supervision of the principal and school culture.

\section{Partial Test (T test)}

Partial test using the T-test aims to test whether each independent variable, namely academic supervision $\left(\mathrm{X}_{1}\right)$ and school culture $\left(\mathrm{X}_{2}\right)$, has a significant effect on the dependent variable, namely the completeness of teacher learning administration (Y ) partially.

Table 6

Partial Test (T-Test) $\mathrm{X}_{1}-\mathrm{Y}$

Coefficients

\begin{tabular}{|c|c|c|c|c|c|}
\hline \multirow{2}{*}{ Model } & \multicolumn{2}{|c|}{$\begin{array}{c}\text { Unstandardized } \\
\text { Coefficients }\end{array}$} & $\begin{array}{c}\text { Standardize } \\
\mathrm{d} \\
\text { Coefficients }\end{array}$ & $\mathrm{T}$ & \multirow{2}{*}{ Sig. } \\
\cline { 2 - 5 } & $\mathrm{B}$ & $\begin{array}{c}\text { Std. } \\
\text { Error }\end{array}$ & Beta & & \\
\hline $37,5267,805.000$ & & & & 4,808 & (Constant) \\
\hline $\begin{array}{l}\text { Academic } \\
\text { Supervision }\end{array}$ & $\begin{array}{r}.067 \\
\text { Sun.000 }\end{array}$ & & & 5,162 & .345 \\
\hline
\end{tabular}

a. Dependent Variable: Completeness Of Learning Administration

Source: Data processing using SPSS version 22.0

Based on the data above it is known that the sig value is $0.00<0.05$ and $t$ count $=5.162>t$ table $=1.9749$, from this data it states that $\mathrm{Ha}_{1}$ is accepted that is, there is an effect of the principal's academic supervision on the completeness of the teaching administration of SMA Negeri teachers in South OKU Regency.

Table 7

Partial Test (T-Test) $\mathrm{X}_{2}-\mathrm{Y}$

\begin{tabular}{|cc|c|c|c|c|c|}
\hline \multirow{2}{*}{ Model } & \multicolumn{2}{|c|}{$\begin{array}{c}\text { Unstandardized } \\
\text { Coefficients }\end{array}$} & $\begin{array}{c}\text { Standardized } \\
\text { Coefficients }\end{array}$ & \multirow{2}{*}{$\mathrm{t}$} & \multirow{2}{*}{ Sig. } \\
\cline { 2 - 5 } & B & $\begin{array}{c}\text { Std. } \\
\text { Error }\end{array}$ & Beta & & \\
\hline \multirow{2}{*}{1} & (Constant) & 37526 & 7805 & & 4808 & .000 \\
& Culture School & .332 & .082 & .301 & 4034 & .000 \\
\hline
\end{tabular}

a. Dependent Variable: Administration Completeness

Learning

Of Resources: Processing data using SPSS version 22

Based on the above data it is known that sig $0.00<0$ , 05 and $\mathrm{t}_{\text {count }}=4.034>\mathrm{t}_{\text {table }}=1.9749$, this means that $\mathrm{Ha}_{2}$ is accepted, which means that there is an influence of school culture on the completeness of the teaching administration of public high school teachers in South OKU Regency.

\section{Simultaneous test (F test)}

Simultaneous test using the $\mathrm{F}$ test is used to determine the effect of the independent variables together on the dependent.

Table 8

Simultaneous Test (Test F)

\begin{tabular}{|c|c|c|c|c|c|}
\hline \multicolumn{6}{|c|}{ ANOVA $^{\mathrm{a}}$} \\
\hline Model & $\begin{array}{l}\text { Sum of } \\
\text { Squares }\end{array}$ & df & $\begin{array}{c}\text { Mean } \\
\text { Square }\end{array}$ & $\mathrm{F}$ & Sig. \\
\hline Regression & 1315,065 & 2 & 657,532 & 43,828 & $.000^{\mathrm{b}}$ \\
\hline Residual & 2355,379 & 157 & 15,002 & & \\
\hline Total & 3670,444 & 159 & & & \\
\hline
\end{tabular}

b. Predictors: (Constant), School Culture, Academic Supervision

Source: Data processing using SPSS version 22

From the table above it can be seen that the probability value (significant) $=0.00<0.05$ and the calculated $\mathrm{F}$ value $=43.828>\mathrm{F}$ table $=3,04$ this states that there is a significant influence between the variable of academic supervision (X1) and school culture (X2) on the completeness of the administration of teacher learning $(\mathrm{Y})$ together.

Table 9

Coefficient of Determination

\begin{tabular}{|c|c|c|c|c|}
\hline Model & $\mathrm{R}$ & $\mathrm{R}$ Square & $\begin{array}{c}\text { Adjusted R } \\
\text { Square }\end{array}$ & $\begin{array}{c}\text { Std. Error of the } \\
\text { Estimate }\end{array}$ \\
\hline 1 & $.599^{\mathrm{a}}$ & .358 & .350 & 3,873 \\
\hline a. & $\begin{array}{l}\text { Predictors: } \\
\text { (Constant), School }\end{array}$ & Culture, Academic \\
\multicolumn{4}{|c|}{ Supervision }
\end{tabular}

Source: Data processing using SPSS version 22

Based on the table above, the $\mathrm{R}$ Square value is 0.358 , thus the termed coefficient is $35.8 \%$ so it can be concluded that the influence of the principal's academic supervision and school culture on the completeness of teacher learning administration together is $35.8 \%$ and 
the remaining $64.2 \%$ is influenced by other factors that are not this variable.

\section{Discussion}

1. The effect of principal academic supervision on the completeness of teacher learning administration.

Based on the results of hypothesis testing, it shows that the principal's academic supervision variable has a significant effect on the completeness of teacher learning administration as indicated by the value of $t$ count greater than $t$ table. From the results of the study 160 teachers as respondents showed that the completeness of the administration of learning for SMA Negeri OKU Selatan District teachers was influenced by the academic supervision of the principal by $34.5 \%$. This means that academic supervision carried out by the principal can encourage and motivate teachers to complete their learning administration.

In line with [19] suggests that academic supervision is supervision that focuses on observations of academic problems, namely those that are directly within the scope of learning activities carried out by teachers to help students while in the learning process. And according to [19], academic supervision can not only help teachers achieve their goals, but also help teachers understand the circumstances and needs of students, as a basis for analysis in planning appropriate teaching and learning activities.

The results of this study are in line with the research conducted by [2], with the title of the study "The Application of Academic Supervision to Improve Teacher Competence in Compiling the Administration of Assessments at SWCU Laboratory Primary Schools", with research results showing that academic supervision can improve teachers' abilities in compiling administrative assessments in learning at the Salatiga Laboratory Elementary School of $26.2 \%$. And research conducted by [20] the results of the study indicate that ongoing academic supervision has been scientifically proven to improve teacher competence in compiling syllabus and lesson plans at SD Negeri 007 Panipahan Darat. This is evidenced by the increase in the number of good teacher syllabuses from $28 \%$ to $75 \%$ after academic supervision. In addition, the number of good quality RPPs also increased from $44 \%$ to $73 \%$.

From the results of the research and relevant research above, it is stated that academic supervision has a significant effect on the completeness of the administration of learning for SMA Negeri teachers in South OKU Regency. In accordance with the opinion expressed by [21] that the implementation of academic supervision is an activity to help teachers develop skills in managing the learning process in order to achieve learning goals. This series of activities includes: (1) monitoring, the objectives of the supervision are teacher teaching activities and student learning assessment activities; (2) assessment, the target of supervision is the preparation of lesson plans, implementation of learning and assessment of learning outcomes of students and;
(3) guidance / training, the target of supervision is the preparation of syllabus and lesson plans, use of media and ICT, assessment of learning outcomes.

2. The influence of school culture on the completeness of teacher learning administration.

From the results hipotes stated that there is significant influence between the variables of school culture on learning administrative requirements, it is shown from the $t$ test results obtained by value $t$ is greater than $\mathrm{t}$ table.From the results of the study 160 teachers as respondents indicate that school culture has an effect on the completeness of the administration of learning for SMA Negeri teachers in South OKU Regency by $33.2 \%$. This means that the school culture, traditions and habits of a school can influence the teacher to be motivated to complete the learning administration.

In line with the opinion of [22], which states that an effective school culture is the values, beliefs, and actions as a result of a collective agreement that gives birth to the commitment of all personnel to carry out consequently and consistently. School culture is a characteristic of the school which can be identified through the values it adopts, the attitudes it has, the habits it displays and the actions shown by all personnel who form a special unit of the school system. With a good school culture, it will increase the commitment and consequence of teachers in carrying out their duties as teachers, one of which is completing the learning administration.

The results of this study are also supported by previous research conducted by [14], which states that there is a significant influence between school culture with the implementation of learning administration by $87.4 \%$. And also research conducted by [4] with the results of the study showing that there is a very significant positive relationship between school culture and the effectiveness of teacher learning by $36.90 \%$.

1. The influence of academic supervision and school culture on the completeness of teacher learning administration.

By looking at the results of the hypothesis using the $\mathrm{F}$ test, theF value calculated is greater than the $\mathrm{F}$ table, this indicates that there is a significant influence between the variables of academic supervision $\left(\mathrm{X}_{1}\right)$ and school culture $\left(\mathrm{X}_{2}\right)$ on the completeness of teacher learning administration (Y) SMA Countries in South OKU Regency together. Based on the table of the coefficient of determination R Square, it can be concluded that the influence of the principal's academic supervision and school culture on the completeness of the teaching administration of SMA Negeri OKU Selatan District teachers together is $35.8 \%$ and the remaining $64.2 \%$ is influenced by other factors which are not this variable.

The results of this study are in accordance with the opinion of [23], that learning administration is an effort to regulate teaching and learning activities in order to achieve effective and efficient learning objectives. The teacher's duties in the teaching and learning process include pedagogical duties and administrative duties. In 
order to fulfill the task of administering learning, the teacher must plan, implement and evaluate learning with various related aspects such as the ability to implement methods, use facilities, create a conducive or pleasant learning climate for students.

The purpose of learning planning according to [9], states that the purpose of learning planning is not only to master the fundamental principles of learning, but also to develop a positive attitude towards learning programs, research and find solutions to learning problems. This confirms that the completeness of a teacher's learning administration cannot be separated from several factors that influence it, including the academic supervision of the principal and the school culture itself.

In addition, there are several relevant research results that strengthen the results of this study. Research conducted by [14] states that there is a significant influence jointly between the academic supervision of the principal and school culture on the completeness of teacher learning administration in elementary schools in Belitang Madang Raya sub-district, East OKU district, amounting to $88.6 \%$ and the remaining $11,4 \%$ is influenced by other factors not examined in this study. Research by [6], research results obtained $73.2 \%$ which indicates that the teaching quality of teachers is able to be influenced by academic supervision and school culture simultaneously, while the remaining 26.85 is influenced by other factors.

\section{CONCLUSION}

From the results of the research and discussion, it can be concluded as follows that there is a significant influence between the academic supervision of the principal and the completeness of the administration of teaching and learning of Public Senior High School teachers in South OKU Regency. , and there is a significant influence jointly between the principal's academic supervision and school culture on the completeness of the administration of learning for SMA Negeri teachers in South OKU Regency.

\section{REFERENCES}

[1] Romlah, O. Y., \& Latief, S. (2021). Empowering the Quality of School Resources in Improving the Quality of Education. Bulletin of Science Education, 1(1), 37-41.

[2] Astuti, S. (2016). Penerapan Supervisi Akademik Untukm Meningkatkan Kompetensi Guru dalam Menyusun Administrasi Penilaian di SD Laboratorium UKWS”. Jurnal Pendidikan dan Kebudayaan, 6(1).

[3] Asnawan, A. (2021). Enhancement Integrated Quality Management in Islamic Education Institutions. Bulletin of Science Education, 1(1), 42-49.
[4] Nurpuspitasari, D. (2019). "Efektifitas Pembelajaran Ditinjau dari Supervisi Akademik Kepala Sekolah dan Budaya Sekolah”. Jurnal Manajemen Pendidikan 7(1).

[5] Fuad, M., Subandi, S., \& Muslan, G. (2021). Teachers' Professionalism and Parents' Motivation in Learning Aswaja at Ma Tri Bhakti At-Taqwa Raman Utara. Bulletin of Pedagogical Research, 1(1), 1-15

[6] Tanggapili, R. (2016)."Hubungan Supervisi Akademik Kepala Sekolah dan Budaya Sekolah dengan Mutu Mengajar Guru SD Se-Kecamatan Konowe". Ojs uho 1(1).

[7] Ferdinandus, L. (2017). "Profesionalisme Guru Ditinjau dari Supervisi Akademik, Budaya Sekolah dan Motivasi Kerja pada SMK Negeri Se- Kabupaten Beli, Provinsi NTT". Jurnal UNNES Educational Management, 6(2).

[8] Muter, N. M. (2012). "Kontribusi Supervisi akademik Kepala Sekolah, Kompetensi Guru Dalam Penyusunan Administrasi Pembelajaran dan Motivasi Kerja Guru terhadap Implementasi Kurikulum Tingkat satuan Pendidikan Pada SMA Negeri Bertaraf Internasional di Kabupaten Gianyar" Jurnal Administrasi Pendidikan Indonesia. Bali: Universitas Pendidikan Ganesha

[9] Sagala, S. (2009). Konsep dan Makna Pembelajaran. Bandung: Alfabeta

[10] Datuk, A. (2020). Sistem Zonasi Sebagai Solusi Bagi Orang Tua untuk Mendapatkan Pendidikan Anak Yang Bermutu Di Kota Kupang. Attractive: Innovative Education Journal, 2(2), 20-33

[11] Arlita, S. E., Ahyani, N., \& Missriani, M. (2020). Pengaruh Kompetensi Akademik dan Motivasi Guru Terhadap Kinerja Guru. Attractive: Innovative Education Journal, 2(3), 8-14.

[12] Suparlan. (2006). Guru Sebagai Profesi. Yogyakarta: Hikayat Publishing.

[13] Sarni, S., \& Muslimah, M. (2021). The Commendable Leadership in Islamic Perspective. Bulletin of Pedagogical Research, 1(1), 163-173.

[14] Wahyuni, S. (2019). "Pengaruh Supervisi Akademik Kepala Sekolah dan Budaya Sekolah Terhadap kelengkapan administrasi pembelajaran Guru Sekolah Dasar di Kecamatan Belitang Madang Raya OKU timur".

[15] Indawati, S. W. (2017). "Pengaruh Budaya Sekolah dan Supervisi Akademik Terhadap Komitmen Guru Madrasah Ibtidaiyah Swasta Kecamatan Pontianak Barat”. Jurnal Pendidikan dan Pembelajaran Katulistiwa 6(5). 
[16] Arikunto, S. (2004). Evaluasi Pendidikan. Jakarta: Rineka Cipta.

[17] Duwi, P. (2010). Teknik Mudah dan Cepat Melakukan Analisis Data Penelitian dengan SPSS. Yogyakarta:Gava Media

[18] Riduwan. (2010). Metode \& Teknik Penyusunan Proposal Penelitian. Bandung: Alfabeta.

[19] Arikunto, S. (2006). Dasar-Dasar Supervisi. Jakarta: Rineka Cipta

[20] Hamid, A. (2017). “Upaya Peningkatan Kompetensi Guru dalam Menyusun Perangkat Pembelajaran melalui Supervisi akademik yang berkelanjutan SDN 007 Panipahan Darat". Jurnal PAJAR (Pendidikan dan Pengajaran) Program Studi Pendidikan Guru Sekolah Dasar FKIP Universitas Riau, 1(2).

[21] Sumarni. (2017). "Pengaruh Supervisi Akademik Pengawas Sekolah, Kpemimpinan Kepala Sekolah dan Lingkungan Kerja terhadap Kinerja Guru SMK Negeri Se-Kecamatan Tamalate Kota Makasar". Jurnal Mirai Management, 2(1).

[22] Komariah, A., \& Cepi, T. (2010). Visionary Leadership Menuju Sekolah Efektif. Jakarta: PT Bumi Aksara

[23] Nisa, H. K. (2017). "Kelengkapan administrasi pembelajaran Guru Pendidikan Jasmani Olah Raga dan Kesehatan Tingkat SD Negeri Sekecamatan Wates Kabupaten Kulon Progo". Journal Students PGSD Penjaskes, 6(4). 